\title{
THE EMERGING DEFENCE OF REPORTAGE
}

\author{
Nadine Zö̈ Armstrong*
}

This article tracks recent developments in the law of defamation, exploring United Kingdom cases where journalists have advanced a defence of reportage. This reportage defence is intended to protect the journalist from a defamation action where there has only been neutral reporting of defamatory allegations which are neither adopted nor embellished. The progress of this nascent defence in several United Kingdom cases is traced, including the most extensive development made in the case of Roberts v Gable. This article then proceeds to elucidate the parameters of the new defence, focussing particularly on the tone of the reporting, how the report has to be of the fact that the statement was made, and the particular context in which the defence has so far succeeded. The justifying rationales for the defence are then explored and critiqued. The potential application of such a defence to a New Zealand context is then considered, revealing how such a development is not plausible in the near future.

\section{INTRODUCTION}

In the United Kingdom it is becoming increasingly questionable whether Lord Denning's observation that "English law does not love tale-bearers"1 continues to hold true. Recent advances in the law of defamation appear to be more accepting towards tale-bearers of the modern age; indeed tale-bearing may be one of the more "responsible" forms of journalism, and actually warrant protection rather than disdain.

This article examines the emerging defence of reportage. In the seminal case of Roberts $v$ Gable Ward LJ described reportage as "the neutral reporting without adoption or embellishment or subscribing to any belief in its truth of attributed allegations of both sides of a political and possibly some other kind of dispute." 2 In order to properly appreciate the development of this new defence the landscape of qualified privilege will first be explored; followed by discussion of the parameters

\footnotetext{
* Submitted as part of the LLB(Hons) programme at Victoria University of Wellington. I would like to acknowledge the assistance of Professor A T H Smith.

1 Dingle v Associated Newspapers Ltd [1964] AC 371, 410 (HL) Lord Denning.

2 Roberts v Gable [2008] QB 502, para 53 (CA) Ward LJ [Roberts v Gable (CA)].
} 
of reportage as demonstrated in several recent cases. Although there remains some controversy over the requirements of this new defence, it is generally accepted that the purpose of the publication must be to report "the fact that it was said." 3 This requirement will be examined as well as the requisite tone of reporting and the context in which the defence operates. Subsequently, by discussing the Reynolds $v$ Times Newspapers $\mathrm{Ltd}^{4}$ (Reynolds) factors the divergence between 'traditional' Reynolds qualified privilege and reportage will be addressed.

The reportage defence has been disguised as a subspecies of the law of qualified privilege ${ }^{5}$ and thus the policy behind it has not been well scrutinised. However, because this defence alters the protection afforded to those publishing defamatory statements it therefore warrants careful consideration of the principles at stake. This is especially so in light of the repetition rule which appears to have been subverted by the introduction of the reportage defence. Other criticisms of the defence include its resistance to defeat by a claim of malice as well as potentially discouraging verification of sources. A brief examination of the New Zealand qualified privilege scene will demonstrate how the reportage defence is not consistent with the current approach, and how any such development would involve significant, possibly unwarranted, changes.

\section{QUALIFIED PRIVILEGE DEVELOPMENTS - SOME BACKGROUND}

\section{A Reynolds v Times Newspapers Ltd ${ }^{6}$}

The Reynolds case marked the start of a more liberal application of the law of qualified privilege to publications made to the world at large. The case concerns proceedings brought by Mr Reynolds against the Times Newspaper, following his resignation as Taoiseach (Prime Minister) of Ireland. ${ }^{7}$ The publication in the British mainland edition was held to carry the defamatory imputation that $\mathrm{Mr}$ Reynolds had deliberately and dishonestly misled the Irish House of Representatives and his cabinet colleagues. ${ }^{8}$

The defendants argued for a generic qualified privilege to cover all political comment published by news media. ${ }^{9}$ Distinguishing political comment from other matters of public concern was held to be unsound. However, it was conceded that common law qualified privilege could be available to

3 Charman v Orion Publishing Group [2008] 1 All ER 750, para 50 (CA) Ward LJ (emphasis in the original) [Charman (CA)].

4 Reynolds v Times Newspapers Ltd [2001] 2 AC 127 (HL) [Reynolds].

5 Roberts $v$ Gable (CA), above n 2, para 60 Ward LJ.

$6 \quad$ Reynolds $v$ Times Newspapers Ltd, above n 4.

7 Ibid, 191 Lord Nicholls.

8 Ibid.

9 Ibid, 192 Lord Nicholls. 
publications in the news media. ${ }^{10}$ The proviso was that it had to be a piece of responsible journalism that satisfied the duty-interest test, or in other words the public had a right to know the particular information. ${ }^{11}$ In order to determine whether these criteria were satisfied Lord Nicholls provided a non-exhaustive list of "matters to be taken into account": 12

(1) The seriousness of the allegation. The more serious the charge, the more the public is misinformed and the individual harmed, if the allegation is not true;

(2) The nature of the information, and the extent to which the subject matter is a matter of public concern;

(3) The source of the information. Some informants have no direct knowledge of the events. Some have their own axes to grind, or are being paid for their stories;

(4) The steps taken to verify the information;

(5) The status of the information. The allegation may have already been the subject of an investigation which commands respect;

(6) The urgency of the matter. News is often a perishable commodity;

(7) Whether comment was sought from the plaintiff. He may have information others do not possess or have not disclosed. An approach to the plaintiff will not always be necessary;

(8) Whether the article contained the gist of the plaintiff's side of the story;

(9) The tone of the article. A newspaper can raise queries or call for an investigation. It need not adopt allegations as statements of fact;

(10) The circumstances of the publication, including the timing.

Lord Nicholls stressed that the importance of each of these factors and others will vary depending on the circumstances of the case. ${ }^{13}$ His Lordship also added a "general exhortation"14 that "[a]ny lingering doubts should be resolved in favour of publication"15 so that the court should be "slow to conclude that the publication was not in the public interest"16 especially where the

10 Ibid, 204 Lord Nicholls.

11 Ibid, 197 Lord Nicholls.

12 Ibid, 205 Lord Nicholls.

13 Ibid.

14 Galloway v Telegraph Group Ltd [2005] EMLR 115, para 154 (QB) Eady J [Galloway (QB)].

15 Reynolds, above n 4, 205 Lord Nicholls.

16 Ibid. 
publication concerns political discussion. ${ }^{17}$ As noted by Godwin Busuttil at the heart of the Reynolds decision "lay the encouragement of high quality, public interest journalism," 18 especially of the investigative variety. ${ }^{19}$

\section{B Jameel and Another v Wall Street Journal Europe (No 3) $\left(\right.$ Jameel) ${ }^{20}$}

Jameel is of particular interest for examining the approach the House of Lords took to Reynolds qualified privilege. The case involved an article in the Wall Street Journal Europe claiming that the Saudi Arabian Monetary Authority was monitoring bank accounts at the request of United States law enforcement agencies, to prevent them from being used wittingly or unwittingly for the funnelling of funds to terrorist organisations. ${ }^{21}$ The plaintiff was among those named as having its accounts monitored. ${ }^{22}$ The defendants successfully established a qualified privilege defence, as the journalism was deemed to be responsible reporting of matters of public concern. ${ }^{23}$ There was a clear split in the House of Lords as to the proper characterisation of the Reynolds defence. The majority (Lords Bingham, Scott and Hope) considered that the Reynolds case still retained the underlying common law test of whether there was a duty to publish the information and a corresponding interest of the public to receive it.

By contrast Lord Hoffmann and Baroness Hale were of the view that the defence in Reynolds is "a different jurisprudential creature from the traditional form of privilege from which it sprang". ${ }^{24}$ They did not think it an embodiment of the "old law" 25 of the duty-interest test. Instead they thought that "[i]f the publication is in the public interest, the duty and interest are taken to exist"; ${ }^{26}$ so the Reynolds defence is best characterised as "a defence of publication in the public interest."27 Although there was conflict in Jameel as to the precise characterisation of the defence there was

17 Ibid.

18 Godwin Busuttil "Current Defamation Issues Reportage: A Not Entirely Neutral Report" (5RB Media and Entertainment Law Conference 2008, London, 24 September 2008), para 1.

19 Ibid.

20 Jameel Mohammed and Another v Wall Street Journal Europe (No 3) [2007] 1 AC 359 (HL) [Jameel].

21 Ibid, para 4 Lord Bingham.

22 Ibid.

23 Ibid, para 111 Lord Hoffmann.

24 Loutchansky v Times Newspapers Ltd (Nos 2-5) [2002] QB 783, para 35 (CA) Lord Phillips MR for the Court.

25 Jameel, above n 20, para 57 Lord Hoffmann.

26 Ibid, para 50 Lord Hoffmann.

27 Ibid, para 146 Baroness Hale. 
unanimous acceptance of a "practical and flexible"28 approach which adhered to the "liberalising intention of the Reynolds decision."29

\section{THE EMERGENCE OF THE REPORTAGE DEFENCE}

\section{A Al-Fagih v HH Saudi Research \& Marketing (UK) Ltd (Al-Fagih) ${ }^{30}$}

Al-Fagih is credited with giving rise to the reportage defence in the United Kingdom. ${ }^{31}$ This case concerned the reporting of a dispute between two prominent members of a Saudi Arabian dissident political organisation (based in the United Kingdom), opposed to the existing Saudi Arabian government. ${ }^{32}$ The newspaper (which supports the Saudi Arabian government and is partly owned by the Saudi Arabian royal family ${ }^{33}$ reported an allegation by Dr Al Mas'aari that the Claimant, Al-Fagih, had spread malicious rumours about him. ${ }^{34}$ After a trial Smith J held that the defence of qualified privilege failed largely because the newspaper had made no attempt to verify this allegation, which was made by an obviously partisan source. ${ }^{35}$ Smith J considered that an attempt at verification would have been very easy. ${ }^{36}$

On appeal, counsel for the defendant (appellant) advanced a Reynolds defence of qualified privilege. ${ }^{37}$ However, he argued that within the broad Reynolds approach considerations such as the fact that the allegation was attributed, unadopted, and in the political sphere, required that the qualified privilege defence should be upheld. ${ }^{38}$ It is thus important to note that no doctrine of "neutral reporting" (as is seen in the United States of America) was actually contended for. ${ }^{39}$ However, it seems that arguing for these "important and often decisive considerations" 40 to warrant

28 Bonnick v Morris [2003] 1 AC 300, para 24 (PC) Lord Nicholls for the Court.

29 Jameel, above n 20, para 35 Lord Bingham.

30 Al-Fagih v HH Saudi Research \& Marketing (UK) Ltd [2002] EMLR 215 (CA) [Al-Fagih (CA)].

31 Roberts $v$ Gable (CA), above n 2, para 34 Ward LJ.

32 Al-Fagih (CA), above n 30, para 2 Simon Brown LJ.

33 Ibid.

34 Ibid, para 3 Simon Brown LJ.

35 Al-Fagih v HH Saudi Research \& Marketing (UK) Ltd (28 July 2000) EWHC (QB) para 58 Smith J [AlFagih (QB)].

36 Ibid, para 62 Smith J.

37 Al-Fagih (CA), above n 30, para 27 Simon Brown LJ.

38 Ibid.

39 Patrick Milmo and WVH Rogers (ed) Gatley on Libel and Slander (10 ed, Sweet \& Maxwell, London, 2004) 461.

40 Al-Fagih (CA), above n 30, para 27 Simon Brown LJ. 
the defence of qualified privilege pinpointed this case as the origin for the subspecies of Reynolds privilege now referred to as reportage.

The beginnings of the reportage defence can be seen in the following features of the Al-Fagih case. The information published was "in the course of what was undoubtedly a political dispute." 41 It was also significant that by reporting these mutual allegations, one or other if not both of the leading members of the political organisation were being shown to be disreputable. ${ }^{42}$ These factors established the public interest. ${ }^{43}$ Latham LJ observed that the reporting of the split in the political group was clearly of significant interest to its readers such that what was said by one side in relation to the other is of considerable interest. ${ }^{44}$ This was so "whether what is said is of high political importance, or merely scurrilous gossip or personal accusations." 45 In summary "[i]t is the fact that the allegation of a particular nature has been made which is in this context important, and not necessarily its truth or falsity." 46

Another important feature is that the allegations were clearly attributed to Dr Al Mas'aari and not adopted by the newspaper. ${ }^{47}$ Simon Brown LJ seemingly thought that this factor entitled the newspaper to publish without attempting verification. However his Lordship acknowledged that there will be circumstances in which verification of a third party's allegations will be appropriate and perhaps even essential. ${ }^{48}$ Latham LJ noted that the need for verification will depend on the facts, commenting that in the context of allegation, counter-allegation and refutation where attribution is clear, verification may be significant only if the allegations are such that the ramifications go well beyond the ambit of the dispute; for example allegations of criminality. ${ }^{49}$

So although there was no argument in Al-Fagih for an expansion of the law to allow a doctrine of "neutral reportage" as exists in the United States of America, ${ }^{50}$ it seems that the features of this

41 Ibid, para 49 Simon Brown LJ.

42 Ibid.

43 Ibid.

44 Ibid, para 65 Latham LJ.

45 Ibid.

46 Ibid.

47 Ibid, para 39 Simon Brown LJ.

48 Ibid, para 51 Simon Brown LJ.

49 Ibid, para 68 Latham LJ.

50 See generally Dorothy A Bowles "Neutral Reportage as a Defense Against Republishing Libel" (1989) 11 Comm \& L, 3. 
case of qualified privilege bear the hallmarks of such a defence and so this case paved the way for further development in the reportage sphere.

\section{B Galloway v Telegraph Group Ltd (Galloway) ${ }^{51}$}

The reportage defence was further explored in the case of Galloway. The Daily Telegraph defendants published articles including documents that were found by its journalists in the Iraqi foreign ministry in Baghdad shortly after the invasion by coalition forces in 2003. ${ }^{52}$ These articles were held to suggest among other things that Mr George Galloway MP had been personally receiving money from Saddam Hussein's regime. ${ }^{53}$ In the High Court, Eady J carefully considered the approach taken in Al-Fagih and identified some significant potential distinctions between $\mathrm{Al}$ Fagih and the facts of Galloway. ${ }^{54}$ It is worth noting that Eady J delivered this judgment before Jameel, but it was not cited to the House of Lords in that case. The distinctions Eady J identified were that although there was a political dimension to the case, this was not an instance of public figures making allegations and cross-allegations and thus giving rise to a dispute which would itself be of inherent public interest. ${ }^{55}$ Furthermore this was "not a case where one or other, or both, of two persons could be shown to be disreputable by the very nature of the allegations being made (whether true or false)." 56 Eady J considered that it would need to be determined whether the defamatory imputations were adopted or implied as true, whether the articles were "fully, fairly and disinterestedly" ${ }^{57}$ reporting the content of the Baghdad documents and Mr Galloway's response, ${ }^{58}$ and whether the articles went beyond reporting the documents and made independent allegations or inferences. $^{59}$

After examining the circumstances of publication Eady $\mathrm{J}$ determined that the defendants were not neutral in their reporting; not only did they adopt the allegations but "[t]hey embraced them with relish and fervour ... [and] went on to embellish them."60 The Court of Appeal upheld Eady J's finding and agreed with his Honour's analysis of the distinctions between Al-Fagih and the present

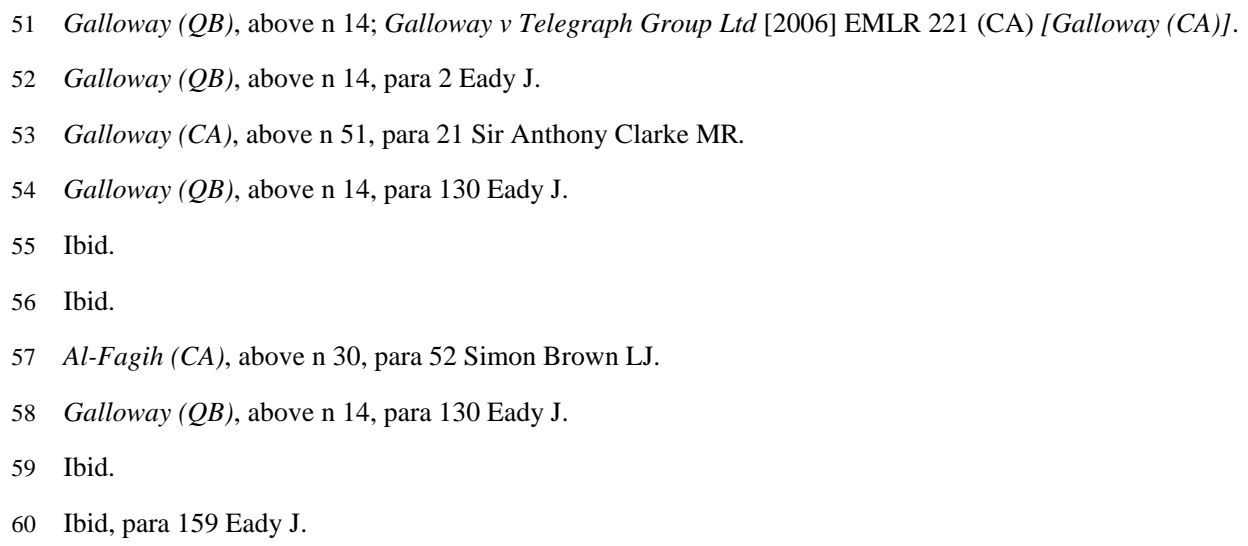


case. ${ }^{61}$ It is unclear how these distinctions would have impacted on the decision had the defence not failed for the reason that the allegations were adopted by the newspaper. As noted by Godwin Busuttil $^{62}$ the Court of Appeal in Galloway apparently thought that although verification of the allegations was not necessary it would still be important to give "Mr Galloway a fair opportunity to respond to them." 63

\section{Roberts v Gable}

1 First instance decision

The most comprehensive exploration of the reportage defence to date was made in Roberts $v$ Gable. This case concerned an article in the Searchlight magazine which formed part of a series of articles intermittently covering a "feud" between different factions of the British National Party in the London area. ${ }^{64}$ The particular article complained of, reported a letter issued by Messrs Hill and Jeffries in reply to accusations made against them by the claimants, Christopher and Barry Roberts. Eady $\mathrm{J}$ analysed the case using the reportage subcategory of qualified privilege.

Eady $\mathrm{J}$ applied the Court of Appeal's analysis in Al-Fagih, and went on to apply the ten factors identified by Lord Nicholls in Reynolds, although noting how these tests do not apply comfortably to a reportage case. ${ }^{65}$ It was found that the allegations were serious, ${ }^{66}$ there was legitimate interest in the subject-matter by the general public and in particular the electorate, ${ }^{67}$ and there was no urgency about the matter. ${ }^{68}$ No steps were taken to verify the information but this was not determined to be fatal "in a reportage case, where the fact of the allegations being made is what is important"; 69 furthermore the source ${ }^{70}$ and status of the information were found to be less significant in the reportage context given the allegations were attributed. ${ }^{71}$ No comment was sought from either claimant but this was deemed reasonable in the circumstances. ${ }^{72}$ The tone of the article

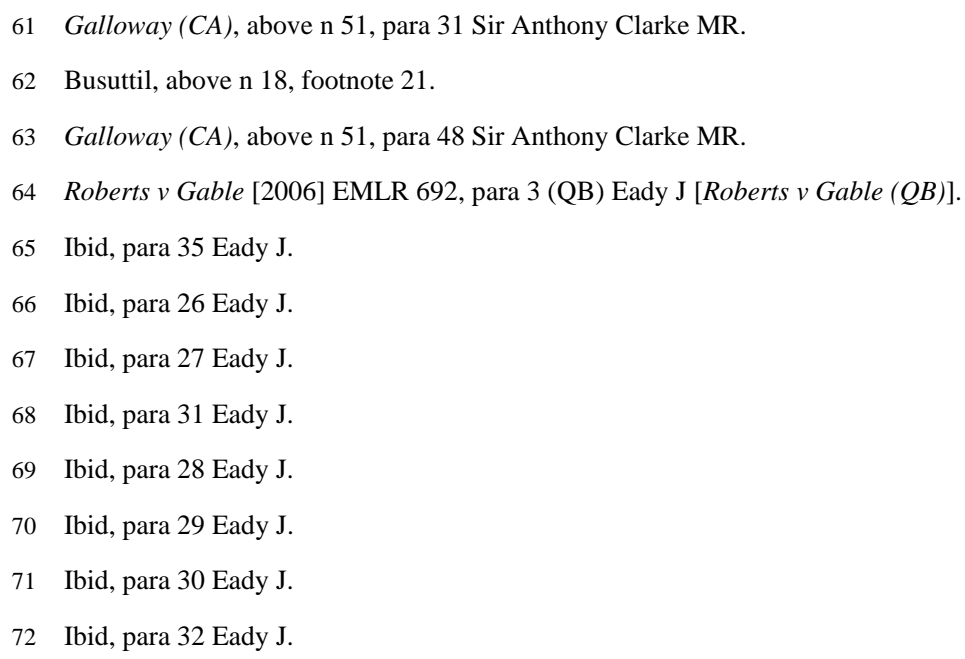


was neutral with the allegations being reported and not adopted; ${ }^{73}$ it was also significant that the dispute was taking place in a political context. ${ }^{74}$ These factors established a duty to publish and a corresponding interest in the public receiving the information; this was especially so because the magazine had already covered the allegations against Messrs Hill and Jeffries and so it was incumbent on it to cover their denials. ${ }^{75}$

\section{Court of Appeal decision}

The Court of Appeal upheld Eady J's finding and approved of his Honour's application of the principles of reportage. Ward LJ (with whom Moore-Bick LJ agreed) ${ }^{76}$ characterised the defence of reportage as it was in Al-Fagih as "a form of, or a special example of, Reynolds' qualified privilege". ${ }^{77}$ Ward LJ believed that reportage cannot be a defence sui generis given that it is founded on the same underlying rationale as Reynolds, which is "the public policy demand for there to be a duty to impart the information and an interest in receiving it". ${ }^{78}$ Furthermore a generic qualified privilege for political speech was denied in Reynolds so a generic qualified privilege for reportage must also be rejected. ${ }^{79}$ Ward LJ then outlined the matters to be taken into account when considering whether there is a defence of reportage. ${ }^{80}$

The first matter Ward LJ identified is that the information must be in the public interest ${ }^{81}$ (which is to be judged at the moment of publication). ${ }^{82}$ Second, contrary to traditional Reynolds privilege "[i]n a true case of reportage there is no need to take steps to ensure the accuracy of the published information." 83 Third, "[t]o qualify as reportage the report, judging the thrust of it as a whole, must have the effect of reporting, not the truth of the statements, but the fact that they were made." 84 Fourth, it is for the judge to establish objectively the effect of the article as a whole, taking into account all the circumstances surrounding the gathering of information, the manner of its

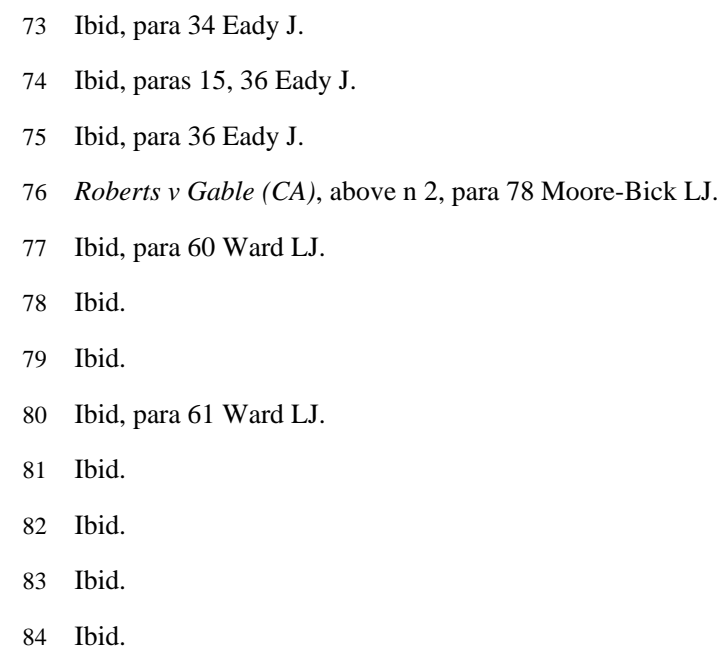


reporting, and the purpose to be served. ${ }^{85}$ Fifth, the report must be unadopted and reported "in a fair, disinterested and neutral way." ${ }^{86}$ The sixth matter is that defendant bears the burden of ensuring that the publication meets the standards of responsible journalism as the concept has developed from Reynolds. ${ }^{87}$ In determining this point reference must be made to all the circumstances of the case and the ten Reynolds factors "adjusted as may be necessary for the special nature of reportage". 88 The seventh matter to be considered is the seriousness of the allegation, which impacts upon the critical question of whether the public has a "right to know the fact that these allegations were being made one against the other". ${ }^{89}$ The more serious the allegation, the more it is required to make a real contribution to the public interest element in the article. ${ }^{90}$ The eighth point is that there is no need for the defendant to be a responsible prominent person or for the claimant to be a public figure. ${ }^{91}$ Finally Ward LJ commented that urgency is relevant such that editorial judgments made in the haste of a pressing deadline may require more allowance to be made than those decisions made with the luxury of time. ${ }^{92}$ His Lordship also commented that the note of sarcasm in the article, and the "unfeigned glee" at having reported this embarrassment to their political enemies was not fatal to the finding of responsible journalism. ${ }^{93}$

Sedley LJ accepted the submission that because the reportage defence modifies the repetition rule (discussed below) ${ }^{94}$ it needs to be treated restrictively. ${ }^{95}$ His Lordship also commented that "nothing in the law denies the reportage defence to a defendant who is taking a perceptible pleasure in reporting the controversy." 96 Sedley LJ, disagreeing with Latham LJ in Al-Fagih, was of the view that "the more personal and scurrilous the content of the reported controversy, the less likely it is that the controversy itself will be a matter of genuine public interest". ${ }^{97}$ Furthermore his Lordship did not think that severe accusations such as those of criminality should require verification,

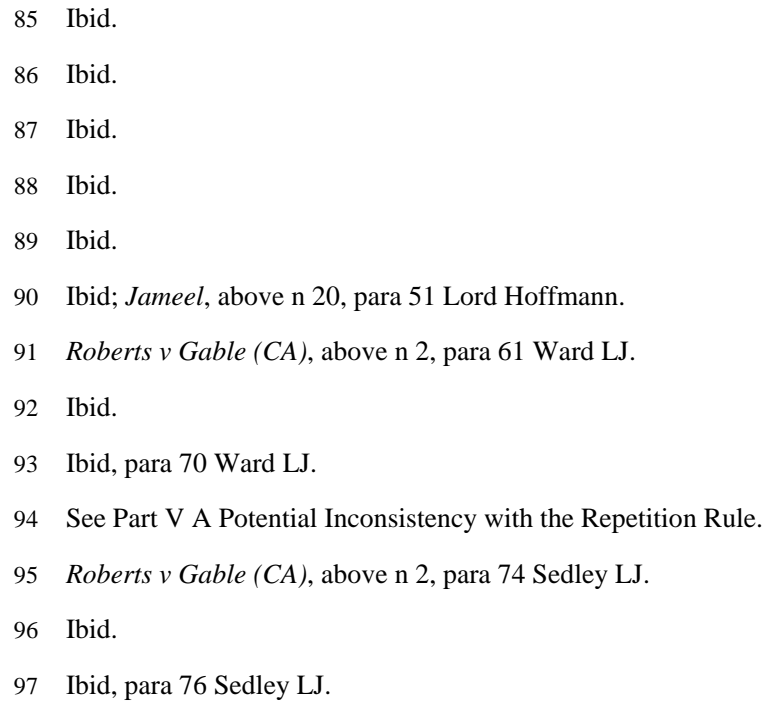


provided that the subject-matter is such as to make the controversy itself a matter of public interest. 98

\section{Charman v Orion Publishing Group Ltd (Charman) ${ }^{99}$}

Charman demonstrates the interaction between the reportage defence and the 'traditional' Reynolds qualified privilege. ${ }^{100}$ The Claimant was an officer in the Metropolitan Police who was seeking damages in respect of allegations made in a book entitled Bent Coppers. ${ }^{101}$ The passages in question bore the defamatory meaning that there were "cogent grounds to suspect Mr Charman abused his position as a police officer by colluding ... in the commission of substantial fraud". ${ }^{102}$ The defence of reportage failed in both the High Court and Court of Appeal, though the work was held to be responsible journalism in the Court of Appeal under the traditional Reynolds approach. ${ }^{103}$ When addressing the argument for a reportage defence Ward LJ applied the considerations outlined in Roberts $v$ Gable.

Ward LJ stressed that the defence will be admitted only if the effect of repeating the allegation is to report the fact the allegation was made and not the truth of the defamatory material. ${ }^{104}$ In Charman this "defining characteristic of reportage is missing" because rather than report the fact that allegations of corruption were made and denied, the effect of the book is to tell the inside story of the corruption. ${ }^{105}$ Ward $\mathrm{LJ}$ found that this attribute was enough to doom the entire reportage defence. ${ }^{106}$ His Lordship emphasised that it is important to determine whether the author has made the allegations his own ${ }^{107}$ and this is a question that need not be complicated by issues of the report's meaning. ${ }^{108}$ Ward $\mathrm{LJ}$ also highlighted the distinction between the bloodhound and watchdog roles of the media; ${ }^{109}$ with reportage protecting only the latter function. Sedley LJ agreed

98 Ibid.

99 Charman (CA), above n 3.

100 Ibid, para 4 Ward LJ.

101 Ibid, para 1 Ward LJ.

102 Ibid, para 2 Ward LJ.

103 Charman (CA), above n 3.

104 Ibid, para 50 Ward LJ.

105 Ibid, para 49 Ward LJ.

106 Ibid.

107 Ibid, para 56 Ward LJ.

108 Ibid, para 55 Ward LJ.

109 Ibid, para 49 Ward LJ. 
that this case could not possibly fall within the bounds of the reportage defence. ${ }^{110}$ Despite failing under the reportage defence the work was deemed to be responsible because this was just "the sort of neutral, investigative journalism which Reynolds privilege exists to protect."111

\section{E Prince Radu of Hohenzollern v Houston (Radu) ${ }^{112}$}

The most recent exploration of the reportage defence is seen in Radu, where the Claimant (the husband of Princess Margarita, daughter of the former King of Romania) ${ }^{113}$ sued over an article in a magazine called Royalty Monthly. ${ }^{114}$ The defamatory effect of the article was that there was a very strong case that the Claimant was an imposter relying on a false document, who had used his rank to deceive people into allowing him access to social circles and official positions, and that he had created a security risk by exposing himself to blackmail, and had falsely claimed to have been adopted by the Hohenzollerns. ${ }^{115}$ Eady $\mathrm{J}$ applied the law of reportage elucidated in the above judgments. Eady J commented that the warning provided by Sedley LJ in Roberts $v$ Gable that this defence "needs to be treated restrictively", ${ }^{116}$ refers to the fact that it is important that the circumstances of each case are examined to make sure that it really is a case of reportage. ${ }^{117}$ Eady $\mathrm{J}$ noted that "an article does not lose the status of 'report' merely by including other material by way of background or journalistic colour, but a reader should be able to recognise what is reporting and what is not." 118 The defamatory allegations must be found in the reporting part in order to be afforded the reportage defence. ${ }^{119}$

Furthermore Eady J stated that the article would have to be carefully balanced so that the readers would be able to ascertain broadly what each side was saying. ${ }^{120}$ The reportage defence was not allowed in Radu as there was no such balance; the scales were heavily tilted against the Claimant as there was no evidence in the article of the Claimant's response. ${ }^{121}$ Eady $\mathrm{J}$ concluded that the

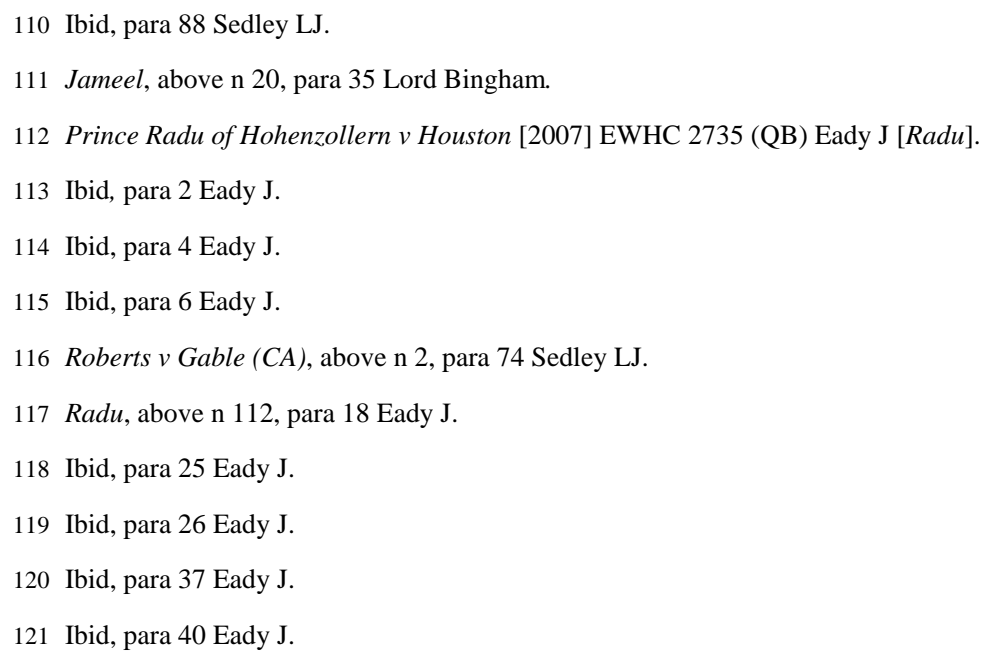


circumstances were unlike those found in Roberts $v$ Gable "where the readers could infer that there were two conflicting accounts but could draw no ready conclusion as to which was correct."122 Therefore it appears that such balance is imperative for the success of the reportage defence.

\section{EXPLORING THE REPORTAGE DEFENCE}

It can therefore be seen that several principles have emerged which are crucial to establishing the defence of reportage. This defence appears to be available in instances of responsible journalism ${ }^{123}$ where the purpose of the report is to convey the fact that certain allegations have been made, ${ }^{124}$ and the report conveys both sides fully fairly and disinterestedly in a neutral way, ${ }^{125}$ without adopting or embellishing any of the allegations. ${ }^{126}$ If these criteria are satisfied and there is a public interest at the time of publication in the fact that the allegations are being made (rather than their truth or falsity), there is no duty upon the author to verify the truth of the allegations. ${ }^{127} \mathrm{~A}$ closer examination of each of the elements of the defence is necessary in order to identify their appropriate ambit of application.

\section{A Tone of the Reporting}

A key feature of the reportage defence is that the piece of journalism is neutrally reported, so that allegations are attributed and not endorsed or embellished. ${ }^{128}$ In Al-Fagih this is summarised by Simon Brown LJ in the phrase "fully, fairly and disinterestedly". ${ }^{129}$ Ward LJ in Charman says the issue is whether the author made the allegations his own by espousing or concurring in the charges, whether it was "a full, fair and accurate report" or whether the author has taken over it and transformed it such that it is no longer a report. ${ }^{130}$ However the mere inclusion of background material is permissible. ${ }^{131}$

As well as the requirement of neutrality, 'tone' has been further discussed in the context of reportage. In Radu Eady $\mathrm{J}$ noted that "reliance on this form of privilege does not entail that any

\footnotetext{
122 Ibid, para 40 Eady J.

123 Roberts v Gable (CA), above n 2, para 61 Ward LJ; Charman (CA), above n 3, para 48 Ward LJ.

124 Al-Fagih (CA), above n 30, para 65 Latham LJ; Roberts v Gable (CA), above n 2, para 61 Ward LJ; Charman (CA), above n 3, para 50 Ward LJ.

125 Al-Fagih (CA), above n 30, para 52 Simon Brown LJ; Roberts v Gable (CA), above n 2, para 61 Ward LJ.

126 Charman (CA), above n 3, para 56 Ward LJ.

127 Al-Fagih (CA), above n 30, para 52 Simon Brown LJ; Roberts v Gable (CA), above n 2, para 61 Ward LJ.

128 Al-Fagih (CA), above n 30, para 67 Latham LJ; Roberts v Gable (CA), above n 2, para 61 Ward LJ.

129 Al-Fagih (CA), above n 30, para 52 Simon Brown LJ.

130 Charman (CA), above n 3, para 56 Ward LJ.

131 Radu, above n 112, para 25 Eady J.
} 
special 'tone' needs to be adopted." 132 Eady $\mathrm{J}$ referred to the comment by Sedley LJ in Roberts $v$ Gable that the reportage defence would not be denied to a defendant "who is taking a perceptible pleasure in reporting the controversy." 133 Ward LJ in Roberts $v$ Gable did not find it significant that the report contained "a note of sarcasm" or that it was reported with "some unfeigned glee" at having embarrassed their political opponents. ${ }^{134}$ It is therefore apparent that within the bounds of neutral reporting there still exists a degree of journalistic licence; even allowing a degree of Schadenfreude.

Sedley LJ in Roberts $v$ Gable believed that Baroness Hale's comment in Jameel that "the tone in which the information is conveyed will be relevant to whether or not the publisher has behaved responsibly in passing it on" 135 did not mean that the reportage defence was to be "a prize for bland journalism", but rather that the defence may be forfeited by a presentation which undermines the public interest it purports to serve. ${ }^{136}$ The tantalising question remains of course at what stage do "perceptible pleasure"137 and "unfeigned glee"138 stray into the realm of an unbalanced report. This will depend on the circumstances of the case and will involve some difficult judgments based on the style of reporting. Regrettably, space precludes further exploration of this point.

Allowing scope for journalistic licence appears to be consistent with emerging jurisprudence from the European Court of Human Rights. In Thoma v Luxembourg (Thoma) it was held that it is not appropriate for the law to insist that journalists should formally distance themselves from the content of a quotation. ${ }^{139}$ In Selistö $v$ Finland it was acknowledged that journalists cannot be expected to act with total objectivity but must be allowed some degree of exaggeration and even provocation. ${ }^{140}$ The principle in Thoma was also affirmed in the case of Verlagsgruppe News GMBH v Austria (Verlagsgruppe), where the Court commented that such a requirement could not be reconciled with the "press's role of providing information on current events, opinions and ideas". ${ }^{141}$ Despite these observations, as Godwin Busuttil notes, "[i]t is a mistake to think that reportage as a

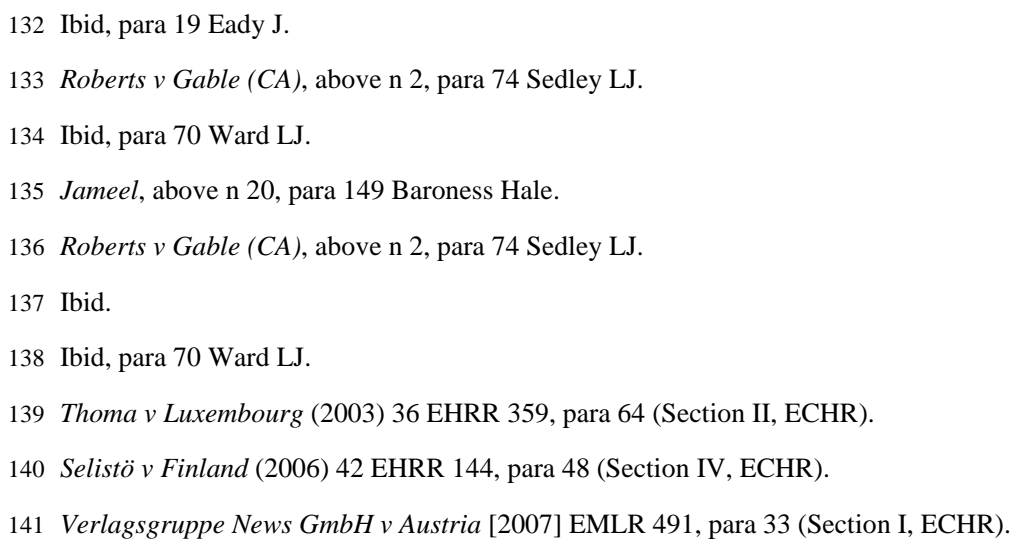


defence is compelled by Strasbourg jurisprudence." 142 Instead these comments are simply useful indicia when considering broader questions as to acceptable tone of reporting.

\section{B A Report of the Fact that the Statement Was Made}

As acknowledged by Ward LJ in Charman, in order to be protected by the reportage defence the purpose and effect of the publication must be to report "the fact that it was said." 143 This distinction is analogous to the rules for admitting hearsay evidence. ${ }^{144}$

In Al-Fagih Latham LJ believed that in the reportage context it would not matter whether what was said was of high political importance or mere scurrilous gossip. ${ }^{145}$ Sedley LJ in Roberts $v$ Gable disagreed, intimating that there may not be a public interest in knowing that allegations of a very personal and scurrilous nature had been made. ${ }^{146}$ With respect, it appears to the author that the more personal and scurrilous the allegations the more the public is informed about the character of the person making them. ${ }^{147}$ Furthermore, if it is the fact of the dispute that is important the subjectmatter should be of little moment. It seems inconsistent to allow reportage to protect neutral reporting of only certain subject-matter, given the House of Lords in Reynolds expressly declined to limit the subject-matter to which qualified privilege applied by rejecting a generic defence for political matters.

The fact that the allegations are made usually serves to tell the reader something about the people making those allegations. ${ }^{148}$ Therefore although there is no specific requirement that the defendant be a responsible prominent person or the claimant be a public figure, ${ }^{149}$ it seems that they must nonetheless be people of sufficient prominence in order to generate a public interest in the fact that allegations were made by or against them. This is alluded to in Roberts $v$ Gable by Ward LJ in the comment "[t]he relevant factors properly applied will embrace the significance of the protagonists in public life". ${ }^{150}$

\footnotetext{
142 Busuttil, above n 18, para 9.5.

143 Charman (CA), above n 3, para 50 Ward LJ (emphasis in the original).

144 Ibid.

145 Al-Fagih (CA), above n 30, para 65 Latham LJ.

146 Roberts $v$ Gable (CA), above n 2, para 76 Sedley LJ.

147 See Steven Price "Defamation - Qualified Privilege" in William Akel Media Law: Rapid Change, Recent Developments (New Zealand Law Society, Wellington, 2008) 77, 89.

148 Al-Fagih (CA), above n 30, para 49 Simon Brown LJ.

149 Roberts v Gable (CA), above n 2, para 61 Ward LJ.

150 Ibid.
} 


\section{Context of Application of the Reportage Defence}

In both cases where the defence of reportage was upheld (Al-Fagih and Roberts $v$ Gable) the publication was made in the course of reporting allegations and counter-allegations made in a political context. It is uncertain how integral both political nature and reciprocity of allegations will be to the success of the reportage defence. Eady J in Roberts $v$ Gable commented that it is "obvious that the political significance of a publication will often be an important factor in determining the merits of a privilege plea." ${ }^{151}$ So whilst not decisive the political nature of a dispute is likely to be significant in establishing the public interest in the fact that the allegations were made.

In Al-Fagih the defence is thought likely to be available where "both sides to a political dispute are being ... reported in their respective allegations and responses." 152 Therefore it seems this defence envisages covering mutual allegations and responses, as was the factual pattern of the case. Latham LJ discussed the allegation and counter-allegation context in Al-Fagih, commenting that the structure of reporting in that case conveyed that the allegation was likely to be met by refutation and/or counter-allegation, which was what subsequently occurred. ${ }^{153}$ Similarly in Roberts $v$ Gable Eady $\mathrm{J}$ noted that there was a duty to publish especially because those making the allegations had already had allegations reported against them. ${ }^{154}$ This strengthened the public interest in the reader being informed and thus the corresponding duty to publish. ${ }^{155}$ In Charman Sedley LJ was of the view that the reportage doctrine could not logically be confined to the reporting of reciprocal allegations, and that "[a] unilateral libel, reported disinterestedly, will be equally protected."156

In Radu, Eady J noted that for reportage to succeed the matter must be carefully balanced so that readers would broadly understand what each side was saying. ${ }^{157}$ Furthermore Eady J stated that the circumstances in Radu were not like those in Roberts $v$ Gable "where the readers could infer that there were two conflicting accounts but could draw no ready conclusion as to which was correct." 158 Thus one of the reasons the reportage defence failed in Radu is the Claimant's side of the story was not reported. In the case of Malik $v$ Newspost Ltd Eady J made the obiter remark that "if both sides of the controversy were fairly and disinterestedly reported, there might be a reportage

\footnotetext{
151 Roberts $v$ Gable (QB), above n 64, para 15 Eady J.

152 Al-Fagih (CA), above n 30, para 52 Simon Brown LJ.

153 Ibid, para 67 Latham LJ.

154 Roberts v Gable (QB), above n 64, para 24 Eady J.

155 Al-Fagih (CA), above n 30, para 67 Latham LJ.

156 Charman (CA), above n 3, para 91 Sedley LJ.

157 Radu, above n 111, para 37 Eady J.

158 Ibid, para 40 Eady J.
} 
defence". ${ }^{159}$ Therefore despite Sedley LJ's comment in Charman it appears that typically reciprocity of allegations is required for reportage.

\section{Responsible Journalism - The Reynolds Factors in the Reportage Context}

Alongside public interest, responsible journalism is a hallmark of Reynolds qualified privilege. Responsible journalism is usually determined by reference to Lord Nicholls' ten non-exhaustive elements identified in Reynolds. Eady J noted in Roberts $v$ Gable that these factors do not appear to fit the reportage template as well as they fit circumstances where the defamatory allegations are adopted, yet it was still right to consider them. ${ }^{160}$ Ward LJ elaborated in Roberts $v$ Gable saying that the publication must meet the standards of responsible journalism which can be ascertained by reference to Lord Nicholls' factors adjusted as may be necessary for the special nature of reportage. ${ }^{161}$ It is therefore important to consider how these factors have been modified by the reportage context.

The first Reynolds factor is the seriousness of the allegations. This factor is specifically listed in Roberts $v$ Gable as one that must be taken into account when determining whether there is a defence of reportage. ${ }^{162}$ The more serious the allegation the more harm will be done to the person's reputation if it is untrue. ${ }^{163}$ Latham LJ in Al-Fagih was of the view that if the allegations were so serious that the ramifications went beyond the ambit of the dispute then this would require verification of the allegation. ${ }^{164}$ Sedley LJ in Roberts $v$ Gable disagreed with this comment instead focusing on the question of whether the subject-matter was in the public interest, rather than how serious the allegations were. ${ }^{165}$ It appears that the more serious the allegation the more important it is that it makes a real contribution to the public interest element in the article. ${ }^{166}$

The second Reynolds factor is whether the subject-matter of the publication is a matter of public concern. ${ }^{167}$ In the reportage context it seems that the interest lies in the fact that the allegations were made and not in their truth or falsity. Yet presumably in some contexts even the fact that the allegations were made will not be in the public interest. This might be the case if neither those

159 Malik v Newspost Ltd [2007] EWHC 3063, para 15 (QB) Eady J.

160 Roberts $v$ Gable (QB), above n 64, para 25 Eady J.

161 Roberts $v$ Gable (CA), above n 2, para 61 (CA) Ward LJ.

162 Roberts v Gable (CA), above n 2, para 61 Ward LJ.

163 Reynolds, above n 4, 205 Lord Nicholls.

164 Al-Fagih (CA), above n 30, para 68 Latham LJ.

165 Roberts v Gable (CA), above n 2, para 76 Sedley LJ.

166 Ibid, para 61 Ward LJ; Jameel, above n 30, para 51 Lord Hoffmann.

167 Reynolds, above n 4, 205 Lord Nicholls. 
making the allegations nor those thereby defamed are public figures or have any other special status. ${ }^{168}$

Greater divergence between traditional Reynolds qualified privilege and the subcategory of reportage can be seen concerning the third and fifth Reynolds factors. The third factor, the source of the information, ${ }^{169}$ is of less significance in a reportage context because "it is not the reliability of either side which matters so much as the nature of the quarrel." 170 So too the fifth Reynolds factor of the status of the information ${ }^{171}$ would differ in a reportage context, because as the allegations are attributed the reader can decide for themselves the reliability of the source.

The greatest divergence exists with respect to the fourth Reynolds factor of steps taken to verify the information. ${ }^{172}$ Indeed it is a defining characteristic of the defence that provided there is neutral reporting of the fact the allegations were made, verification is unnecessary. ${ }^{173}$ The reason for this divergence from traditional expectations of responsible journalism is again because it is the fact that the statements are made which is important. ${ }^{174}$ As Ward LJ describes in Roberts $v$ Gable the author "is absolved from that responsibility because he is simply reporting in a neutral fashion the fact that it has been said without adopting the truth." 175 Presumably it would be necessary to ensure that the person to whom the allegation is attributed did in fact make it, but it would not be necessary to verify the truth of the allegation itself. In Roberts $v$ Gable Sedley LJ acknowledges that whether responsible journalism calls for verification "will be a case- and fact-specific question,"176 although his Lordship concedes that in a great many cases verification of the truth will be beside the point. ${ }^{177}$

It is questionable whether ease of verification is relevant. In both Al-Fagih and Roberts $v$ Gable verification of the truth of the allegations could arguably be regarded as more difficult. However there are conflicting opinions as to precisely how onerous verification would have been in Al-Fagih: whilst Simon Brown LJ seems to imply that such verification would have been difficult, ${ }^{178}$ Smith $\mathrm{J}$

168 See Part IV B A Report of the Fact that the Statement Was Made

169 Reynolds, above n 4, 205 Lord Nicholls.

170 Roberts v Gable (QB), above n 64, para 29 Eady J.

171 Reynolds, above n 4, 205 Lord Nicholls.

172 Ibid.

173 Al-Fagih (CA), above n 30, para 52 Simon Brown LJ; Roberts v Gable (CA), above n 2, para 61 Ward LJ.

174 Roberts $v$ Gable (QB), above n 64, para 28 Eady J; Roberts v Gable (CA), above n 2, para 61 Ward LJ.

175 Roberts $v$ Gable (CA), above n 2, para 61 Ward LJ.

176 Ibid, para 76 Sedley LJ.

177 Ibid.

178 Al-Fagih (CA), above n 30, para 50 Simon Brown LJ. 
(with whom Godwin Busuttil agrees) ${ }^{179}$ thought that it would be very easy. ${ }^{180}$ Irrespective of these differing opinions the Court of Appeal in Al-Fagih did not hold that it was a straightforward matter to verify. Therefore perhaps it is implicit in the defence of reportage that neutral reporting will only absolve the author of a requirement to verify the truth of the allegations, if such verification would require more than just a simple check. Indeed such a caveat would be consistent with the notion of responsible journalism and would prevent the defence of reportage from undermining this standard which the law has strived to enforce.

The sixth Reynolds factor is the urgency of the matter, ${ }^{181}$ Ward LJ in Roberts $v$ Gable listed this as a factor to be taken into account when considering whether there is a reportage defence. ${ }^{182}$ It is unclear precisely how this factor should apply in a reportage context. Usually the less urgent the publication is the more incumbent it is upon a responsible journalist to verify the accuracy of the material to be published; however as mentioned above there is no such duty to verify in a reportage context. Perhaps if the publication was made hastily in order to comply with an urgent deadline, more allowance could be made when determining whether the other criteria of the reportage defence are met, such as neutrality and the report being of the fact that the statements were made and not their truth or falsity.

The seventh Reynolds factor is whether comment was sought from the plaintiff. ${ }^{183}$ It seems that this point is not crucial because it is the fact of the cross-allegations which is important rather than the extent of their accuracy. ${ }^{184}$ On appeal in Roberts $v$ Gable Sedley LJ commented that to suggest it was irresponsible to publish without first soliciting the claimant's side of the story was "not entirely in touch with reality." 185 Therefore this factor is likely to be less significant in a reportage context.

The eighth factor identified by Lord Nicholls in Reynolds is whether the article contained the gist of the plaintiff's side of the story. ${ }^{186}$ This factor seems intrinsic to the crucial requirement of the reportage defence identified by Eady $\mathrm{J}$ in Radu that the report must be carefully balanced, such that the readers can broadly understand what each side was saying. ${ }^{187}$ The ninth Reynolds factor is that

179 Busuttil, above n 18, para 9.3.

180 Al-Fagih (QB), above n 30, para 62 Smith J.

181 Reynolds, above n 4, 205 Lord Nicholls.

182 Roberts $v$ Gable (CA), above n 2, para 61 Ward LJ.

183 Reynolds, above n 4, 205 Lord Nicholls.

184 Roberts v Gable (QB), above n 64, para 32 Eady J.

185 Roberts v Gable (CA), above n 2, para 74 Sedley LJ.

186 Reynolds, above n 4, 205 Lord Nicholls.

187 Radu, above n 112, para 37 Eady J. 
of tone of the article; ${ }^{188}$ as outlined above, for the reportage defence to succeed the tone must be neutral and the allegations must not be adopted. ${ }^{189}$ The tenth Reynolds factor is that the circumstances of the publication including the timing must be taken into account. ${ }^{190}$ This factor seems equally applicable in the reportage context. In summary, however, it seems that there does need to be some considerable adjustment to certain Reynolds factors in order to appropriately apply them to the reportage defence.

\section{EVALUATING THE REPORTAGE DEFENCE}

\section{A Potential Inconsistency with the Repetition Rule}

The repetition rule provides that it is not a defence to a defamation action for the defendant to prove that he was purely repeating what he had been told. ${ }^{191}$ Every republication of a libel is treated as a new libel, and each publisher is liable as if the defamatory statement had originated with them. ${ }^{192}$ In Truth (NZ) Ltd $v$ Holloway the justice of the rule was demonstrated because in that case a defamatory statement made by Mr Judd was repeated by a newspaper and broadcast to the people at large, thereby considerably increasing the damage done to the plaintiff's reputation. ${ }^{193}$ In Stern v Piper the repetition rule is traced back as early as $1829,{ }^{194}$ and Hirst LJ comments that it is supported by a weight of authority, having gained the final seal of approval from the House of Lords in Lewis $v$ Daily Telegraph (Lewis). ${ }^{195}$ In Lewis the rule is expressed as having the effect that "a hearsay statement is the same as a direct statement"196 so that "repeating someone else's libellous statement is just as bad as making the statement directly". ${ }^{197}$ Simon Brown LJ comments in Stern v Piper that "[t]he very existence of the law of privilege to cover fair and accurate reporting of proceedings surely postulates that otherwise such reports would fall foul of the repetition rule."198

188 Reynolds, above n 4, 205 Lord Nicholls.

189 Al-Fagih (CA), above n 30, para 52 Simon Brown LJ; Roberts v Gable (CA), above n 2, para 61 Ward LJ.

190 Reynolds, above n 4, 205 Lord Nicholls.

191 Stern v Piper [1997] QB 123, 128 (CA) Hirst LJ.

192 Patrick Milmo and WVH Rogers (ed) Gatley on Libel and Slander (10 ed, Sweet \& Maxwell, London, 2004) 171; quoted with approval in Truth (NZ) Ltd v Holloway [1960] 1 WLR 997, 1002-1003 (PC) Lord Denning for the Court.

193 Truth (NZ) Ltd v Holloway [1960] 1 WLR 997, 1003 (PC) Lord Denning for the Court.

194 Stern v Piper, above n 191, 129 Hirst LJ.

195 Ibid, 134 Hirst LJ.

196 Lewis v Daily Telegraph [1964] AC 234, 284 (HL) Lord Devlin [Lewis].

197 Ibid, 260 Lord Reid.

198 Stern v Piper, above n 191, Simon Brown LJ. 
The courts have taken differing approaches to this rule in the recent cases featuring reportage. In Al-Fagih arguments that the defence of reportage was inconsistent with the repetition rule were dealt with by characterising the repetition rule as relating only to the defence of justification, and thus it was deemed not relevant to the field of privilege. ${ }^{199}$ In Roberts $v$ Gable Ward LJ applied the same approach. ${ }^{200}$ However Sedley LJ accepted that the reportage defence had to be treated carefully as it modified the repetition rule, although exactly how it modified the rule his Lordship did not say. ${ }^{201}$ In Galloway Eady $\mathrm{J}$ in the High Court noted that it was important to ensure on the facts of any particular case that it really is a reportage case and that "the defendant is not simply seeking to flout the disciplines underlying the repetition rule." 202 The Court of Appeal in Galloway refer to the reportage defence as an exception to the repetition rule. ${ }^{203}$ Therefore there appears to be differing opinions as to whether the reportage defence is consistent with the repetition rule or whether it is an exception.

To evaluate these differing opinions it is necessary to further explore the repetition rule; clearly it is designed to prevent the repetition of libellous statements and thus "to protect the individual's right to his reputation". ${ }^{204}$ As well as the protection of reputation Eady J notes in Galloway that it also serves to prevent the public being misinformed. ${ }^{205}$ The policy inherent in this rule is that repetition does not lessen the defamatory meaning of a statement, nor does it make the repeater less culpable than the person who originally made the statement. By contrast the reportage defence seems to protect certain repeated statements on the assumption that they are less defamatory because they are reporting only the fact that the defamatory remark was made. ${ }^{206}$ Therefore when considering the policy behind the repetition rule it clearly appears to be "fundamentally incompatible"207 with the reportage defence.

The repetition rule is not designed only to prevent people escaping liability in defamation through the defence of justification (by proving that somebody else did in fact make the libellous comment), but rather the purpose is to attribute liability for any republication of defamatory statements. As noted by Arden LJ in Curistan v Times Newspapers Ltd, "the policy of the rule

199 Al-Fagih (CA), above n 30, para 36 Simon Brown LJ.

200 Roberts $v$ Gable (CA), above n 2, para 59 Ward LJ.

201 Ibid, para 74 Sedley LJ.

202 Galloway (QB), above n 13, para 124 Eady J.

203 Galloway (CA), above n 51, para 26 Sir Anthony Clarke MR.

204 Curistan v Times Newspapers Ltd [2008] EWCA Civ 432, para 2 Arden LJ.

205 Galloway $(Q B)$, above n 14, para 124 Eady J.

206 See Part V C 1 Arguments for the reportage defence.

207 Busuttil, above n 18, para 9.2. 
appears potentially to apply in all circumstances and irrespective of whether the meaning of a statement is that the publisher is only reporting that a statement has been made without adopting or endorsing it." 208 It is apparent that prior to the extension of qualified privilege by Reynolds often the only possible avenue for exculpation by a defendant who did publish such a repetition was by way of justification. However the spirit of the rule was always to prevent repetition; thus it would seem to be concerned with repetition of libel regardless of which defence the defendant seeks to advance. Therefore it is the author's view that in the cases where the repetition rule has been regarded as limited only to the defence of justification, it has been dismissed too lightly based on its historical origins.

\section{B Further Criticisms of the Reportage Defence}

In Roberts $v$ Gable counsel for the appellants, Mr Tomlinson QC, argued that the defence of reportage disrupted the balance between freedom of expression and protection of reputation. It was Mr Tomlinson's view that the absence of a requirement of verification created an unacceptably wide "free fire zone". ${ }^{209} \mathrm{Mr}$ Tomlinson argued that responsible journalism demanded verification and that the reportage defence should only be allowed when the following conditions are satisfied: ${ }^{210}$

(1) there is a continuing and active public dispute on a matter of public interest

(2) where the urgency of the matter makes verification in the ordinary way difficult or undesirable

(3) the reported allegations are attributed and not adopted

(4) the reported allegations do not involve misconduct which has wider ramifications - that is misconduct which potentially exposed those responsible to third party sanctions.

These could serve as desirable parameters for the reportage defence as they would circumvent the uncertainty as to whether lack of verification is allowable in all circumstances. However it would undoubtedly be difficult to decide at the outset of a public dispute, precisely how "continuing and active" the dispute would be. The fourth point seems to limit the nature of the allegations being made. Such a limitation is potentially inconsistent with the rationale of the reportage defence, which is to protect certain publications where the purpose is to report the fact that the allegations were made. Perhaps these parameters would be a convenient method of restraining the defence of reportage so that any incursion on the rationale of the repetition rule would only occur in a limited set of circumstances.

208 Curistan $v$ Times Newspapers Ltd, above n 204, para 2 Arden LJ.

209 Roberts v Gable (CA), above n 2, para 30 Ward LJ.

210 Ibid, para 29 Ward LJ. 
A similar concern pointed out by Godwin Busuttil is that reportage seems to be "an absolute privilege in all but name: a privilege which permits reporting of unverified defamatory allegations, which cannot (in reality) be defeated by proof of malice." ${ }^{211}$ This concern arises because it seems very difficult to establish the requisite standard of reckless indifference to truth or falsity that is necessary in order to prove malice. ${ }^{212}$ Simon Brown LJ decided in Al-Fagih that malice could not be found (and therefore the defence of qualified privilege could not be defeated) merely by proving that the defendant failed to verify the allegations; instead it would have to be shown that the dominant motive for publishing was to injure the claimant. ${ }^{213}$ Eady J observed in Lillie \& Reed $v$ Newcastle City Council that although a finding of malice on such grounds is possible it is a remote possibility in light of recent authorities. ${ }^{214}$ The concern therefore is that there is no safeguard for reputation because the publisher is not obliged to verify the allegations in order to be protected by the reportage defence, and the person defamed is unlikely to be able to defeat this defence through a claim of malice. ${ }^{215}$

\section{Rationale of the Reportage Defence}

Surprisingly there has been little consideration of whether this defence is warranted. This is because it has been regarded as a subspecies of Reynolds qualified privilege; "a special kind of responsible journalism but with distinctive features of its own" and thus "the underlying rationale justifying the defence is the public policy demand for there to be a duty to impart the information and an interest in receiving it". ${ }^{216}$ However to accept this basis without further consideration is to ignore the unique characteristics of reportage. This defence seems to run counter to the orthodoxy that "repeating someone else's libellous statement is just as bad as making the statement directly". ${ }^{217}$

\section{Arguments for the reportage defence}

Reportage permits the neutral recounting of defamatory statements of fact, which at first glance hardly seems to promote the "common convenience and welfare of society". ${ }^{218}$ However, the principal tenet of the defence, as emphasised by Ward LJ in Charman is "the effect of the report is not to adopt the truth of what is being said, but to record the fact that the statements which were

211 Busuttil, above n 18, para 9.4.

212 Ibid.

213 Al-Fagih (CA), above n 30, para 55 Simon Brown LJ.

214 Lillie \& Reed v Newcastle City Council [2002] EWHC 1600, para 1091 (QB) Eady J.

215 Busuttil, above n 18, para 9.4.

216 Roberts $v$ Gable (CA), above n 2, para 60 Ward LJ.

217 Lewis, above n 196, 260 Lord Reid.

218 Toogood v Spyring (1834) 149 ER 1044, 1050 Parke B. 
defamatory were made."219 Ward LJ goes on to emphasise this point saying "[n]o matter how overwhelming the public interest, it is not reportage simply to report with perfect accuracy and in the most neutral way the defamatory allegations A has uttered of B."220 It therefore appears that the implicit rationale of the reportage defence is that the publishers are under a duty to report the fact that defamatory allegations were made by A against B when there is a legitimate public interest in knowing this fact. This rationale could potentially explain why the repetition rule can be circumvented; if on the construction of the article it is just a report of the fact that the statement was made, then it should not be classed as repeating the allegation but only reporting this fact. Although the allegation may be reproduced verbatim within the article, the availability of the defence should hinge on the thrust of the article as a whole. One could draw a tenuous analogy to an argument concerning an antidote to the bane; ${ }^{221}$ that because the article is not adopting the allegation but rather just impartially reporting the fact that it was made, this neutralises the effect of repeating the libel. Even if the style of the reporting cannot properly be regarded as neutralising its defamatory effect, the inclusion of the defamatory statement is ancillary to the purpose of the article.

Another potential justification for the reportage defence is that it is a concession to the demands of journalism and the often onerous task of verifying allegations, thus allowing the public to receive the newsworthy information in a timely fashion. This is alluded to by Simon Brown LJ in Al-Fagih who comments, "[i]n this situation it seems to me that the public is entitled to be informed of such a dispute without having to wait for the publisher, following an attempt at verification, to commit himself to one side or the other."222 This justification could explain why the only successful cases of the reportage defence (Al-Fagih and Roberts $v$ Gable) have been instances where verification of the truth of the allegations was likely to have been a relatively difficult (and presumably timeconsuming) task.

Some may say that a desirable consequence of the defence is to prevent defamed individuals going for the deeper pockets and pursuing defamation actions against the media, instead restricting them to seeking redress from the instigator of the statement. However it must be remembered that by the media reporting this allegation it serves to increase significantly the width of dissemination of the statement and thus the damage done to the claimant's reputation.

\section{Criticisms of the reportage rationale}

Whilst for the purposes of the defence subtle distinctions in language mark the difference between repeating an allegation and reporting the fact that it was said, it is debatable whether these

219 Charman (CA), above n 3, para 48 Ward LJ.

220 Ibid, para 50 Ward LJ.

221 Charleston v Newsgroup Newspapers Ltd [1995] 2 AC 65 (HL).

222 Al-Fagih (CA), above n 30, para 52 Simon Brown LJ. 
changes to the style of the reporting have such a significant effect on the minds of the ordinary reasonable reader of the publication. By simply ensuring that the report is neutral, unadopted and the thrust of it is the fact that the statement was made, one does not necessarily avoid the public drawing conclusions as to the truth of the defamatory statement; which they would have been unable to draw but for the publication of the article. Steven Price alludes to this point in saying "[e]ven the most neutral of reports is still publishing what may be a very damaging allegation, and surely the possibility of truth is a key part of what makes it newsworthy."223 Furthermore Godwin Busuttil notes "[i]n reality, damage to reputation, if there has been any, is caused by the appearance of the allegation in a newspaper, regardless of whether the journalist positively subscribes to its truth or not."224

If the public interest which mandates the publication lies in the fact that the defamatory allegations are made, one wonders why it is even necessary to include the allegations. A bare report of the fact that defamatory allegations were made by A against B, could fairly be said to have an equivalent public interest value to an otherwise identical article that included the allegation; yet it is obvious that the public would be much less inclined to read the former article. If the defamatory allegations are to continue to be included in such reports perhaps the author should be required to explicitly record that they do not adopt or endorse the allegations instead of leaving the reader to imply this from the style of the report.

Reporting the fact that the allegation was made is said to be in the public interest as it conveys information to the public about the character of the accuser; but it seems unjust that such circumstances should therefore warrant tarnishing the reputation of another. In Al-Fagih it was said that the report went to show that one or other if not both of the individuals concerned were being shown to be disreputable. ${ }^{225}$ Assuming only one of the individuals was actually acting disreputably (by defaming the other) why then should the other be defamed merely to portray this disreputable conduct?

\section{Further implications of the defence}

It is plausible that the neutral reportage defence may entice journalists to adopt this method of expression rather than pursuing investigative avenues in their "bloodhound" role, which was discussed in Charman as not falling within the ambit of the reportage defence. ${ }^{226}$ Prior to the reportage defence a defendant could only avoid liability through a defence of qualified privilege if they could show truly responsible journalism by rigorously adhering to the Reynolds factors. Now it

223 Price, above n 147, 89.

224 Busuttil, above n 18, para 9.2.

225 Al-Fagih (CA), above n 30, para 49 Simon Brown LJ.

226 Charman (CA), above n 3, para 49 Ward LJ. 
seems that such effort can be avoided merely by writing neutrally. This seems to foster the mere repetition of gossip which will sell newspapers through scandal rather than carefully researched investigative journalism; all on the pretence that the ordinary reasonable reader will not draw conclusions as to the truth or falsity of the reported allegations.

The absence of verification under the reportage defence also gives rise to uncertainty. What will become of the defendant who undertakes some attempt at verification that is insufficient to satisfy the normal Reynolds standard of responsible journalism; have they then foregone their opportunity for a reportage defence? In Al-Fagih Simon Brown LJ whilst careful to convey that it would not necessarily always be the case, commented that "in the present context verification could even be thought inconsistent with the objective reporting of the dispute."227 It remains to be seen what impact attempt at verification would have on the availability of the reportage defence.

In the event of failing to establish the defence of reportage, the fallback option would be traditional Reynolds qualified privilege which will not normally grant protection to a publisher who has not taken reasonable steps to verify the truth and accuracy of what is published. ${ }^{228}$ This difficulty is acknowledged by Sedley LJ in Charman: 229

It is the very dependence of a reportage defence on the bald retailing of libels which makes it forensically problematical to fall back upon an alternative defence of responsible journalism. Pleaders may need to decide which it is to be.

\section{Conclusions on rationale}

In the author's opinion attempts to find a sound principle for the reportage defence are most unsatisfactory. If there is enough public interest in knowing of the fact that allegations were made, the defence should be confined to just that, and as such it should be no more than "a prize for bland journalism". ${ }^{230}$ If journalists wish to sensationalise their articles by the inclusion of defamatory remarks they should not be able to hide behind the excuse that these were made by another. The absence of verification seems too lenient a concession to journalists given that one would assume the perpetrator of the allegation (with whom the journalist must have had some contact) would be in a prime position to be able to verify the truth of it.

227 Al-Fagih (CA), above n 30, para 50 Simon Brown LJ.

228 Roberts v Gable (CA), above n 2, para 61 Ward LJ.

229 Charman (CA), above n 3, para 91 Sedley LJ.

230 Roberts $v$ Gable (CA), above n 2, para 74 Sedley LJ. 


\section{Relevance to the New Zealand Context}

The current approach to qualified privilege in New Zealand is found in the cases of Lange $v$ Atkinson (Lange). ${ }^{231}$ These cases elucidated a defence that protects "generally-published statements which directly concern the functioning of representative and responsible government". ${ }^{232}$ Thus there exists a subject-matter test which restricts Lange qualified privilege to protecting only political speech. The validity of this restriction has recently been challenged in the High Court decision of Osmose New Zealand $v$ Wakeling (Osmose) which appeared to extend the requisite subject-matter to merely that which is in the public interest; ${ }^{233}$ especially where it can be "loosely ... defined as of a political nature." 234 In New Zealand the distinction between occasion of privilege and misuse of the occasion has been maintained. ${ }^{235}$

Lord Nicholls commented in the Privy Council decision in Lange that "striking a balance between freedom of expression and protection of reputation calls for a value judgment which depends upon local political and social conditions."236 Therefore when considering the application of the reportage defence to a New Zealand context reference must be made to such conditions. In Lange $^{237}$ the Court of Appeal decided that the balance struck in Reynolds was not appropriate for the political and social conditions of New Zealand; one must therefore consider whether these conditions would similarly obstruct the application of the reportage defence.

Among the distinguishing factors mentioned in Lange were the "differences between the responsibility and vulnerability of the media in New Zealand and in the United Kingdom". ${ }^{238}$ Such distinctions would be significant if the opportunity arose to decide whether to introduce a defence of reportage into New Zealand. In a very tentative generalisation the Court of Appeal in Lange commented that "it is possible to say that New Zealand has not encountered the worst excesses and irresponsibilities of the English national daily tabloids." 239 There is no reason to believe that this gap in media climate between the United Kingdom and New Zealand has changed, and thus any

\footnotetext{
231 Lange v Atkinson [1997] 2 NZLR 22 (HC); Lange v Atkinson [1998] 3 NZLR 424 (CA); Lange v Atkinson [2000] 1 NZLR 257 (PC); Lange v Atkinson [2000] 3 NZLR 385 (CA).

232 Lange v Atkinson [2000] 3 NZLR 385, para 10 (CA) Judgment of the Court.

233 Price, above n 147, 82.

234 Osmose New Zealand v Wakeling [2007] 1 NZLR 841, para 45 (HC) Harrison J.

235 Lange v Atkinson, above n 232, para 5 Judgment of the Court.

236 Lange v Atkinson [2000] 1 NZLR 257, 261 (PC) Lord Nicholls.

237 Lange v Atkinson [2003] 3 NZLR 385 (CA) Judgment of the Court.

238 Ibid, para 33 Judgment of the Court.

239 Ibid, para 34 Judgment of the Court.
} 
decision to allow a reportage defence could not be justified purely on the basis of following the United Kingdom approach.

Assuming it was deemed appropriate to introduce the defence into New Zealand, the most significant change would be to the subject-matter restriction mentioned above. The reportage defence as it is formulated in the United Kingdom would considerably extend the width of protection of qualified privilege for widely disseminated statements; albeit only for reporting style journalism. As Steven Price notes if the defence were introduced in New Zealand, it would make little sense to confine the subject-matter according to the Lange test; ${ }^{240}$ if such a restriction were to be imposed it would be unlikely that the defence would afford any significant further protection than already exists under Lange.

The principal feature of the reportage defence is that in certain circumstances verification of the truth of the statements is not required. Although the Court of Appeal in Lange held that consideration of the steps taken to verify the information are not relevant to the inquiry of whether the occasion is privileged, ${ }^{241}$ it appears that verification may be relevant to the question of misuse of occasion of privilege. In New Zealand misuse of the occasion of privilege is governed by section 19 of the Defamation Act 1992. In interpreting this section the Court of Appeal in Lange comments that "the privilege may well be lost if the defendant takes what in all the circumstances can fairly be described as a cavalier approach to the truth of the statement." 242 Given that no verification is required under the reportage defence this might exonerate even those defendants who were cavalier about the truth, provided that the publication was a neutral, unadopted report of the fact that the allegations were made. This feature of the defence might serve to broaden the reach of qualified privilege even if the subject-matter restriction was maintained.

As indicated by Steven Price, if a reportage defence were to be introduced into New Zealand it would also need to be considered whether neutrality would be an aspect of the qualifying occasion or relevant to whether it was misused, or both. ${ }^{243}$ Regrettably space prevents further exploration of this point.

It appears that logical progression towards a defence of reportage in New Zealand would first require relaxation of the subject-matter requirement of Lange; which may indeed have been achieved in Osmose. From there would follow a principled consideration (which space here precludes) of whether in the social and political climate of New Zealand it would be desirable to allow such a defence.

240 Price, above n 147, 88.

241 Lange v Atkinson, above n 232, para 38 Judgment of the Court.

242 Ibid, para 47 Judgment of the Court.

243 Price, above n 147, 88. 


\section{CONCLUSION}

The emergence of the reportage defence is an example of what Lord Nicholls in Reynolds has called the "elasticity of the common law principle". ${ }^{244}$ Whilst several features of the defence have been elucidated in the various cases; their precise ambit of application remains uncertain. At present the only successful cases of reportage involved allegations and counter-allegations made in the context of a dispute between political figures.

It appears difficult to find a satisfactory principled basis for the defence of reportage. It is best viewed as a set of circumstances in which failure to verify the truth of the allegations is nevertheless found to be responsible; perhaps as a consequence of the "general exhortation" 245 in Reynolds that "[a]ny lingering doubts should be resolved in favour of publication."246

In the author's opinion the reportage defence is not desirable and is unwarranted both in light of principle and precedent (namely the repetition rule). Given the public interest lies only in the fact that the defamatory statements were made by, or against, somebody perhaps inclusion of the defamatory remark is unnecessary to discharge the duty upon the publisher. Alternatively the model proposed by Mr Tomlinson QC in Roberts $v$ Gable could be adopted to restrain the application of the defence.

In light of the unconvincing principled basis for the reportage defence New Zealand should be cautious in following this approach. This is especially so given the different political and social circumstances in New Zealand which warranted rejecting the Reynolds approach. Furthermore the reportage defence would drastically widen the subject-matter for which a qualified privilege defence is available.

\footnotetext{
244 Reynolds, above n 4, 204 Lord Nicholls.

245 Galloway (QB), above n 14, para 154 Eady J.

246 Reynolds, above n 4, 205 Lord Nicholls.
} 
